\title{
The Disclosure of Leniency Statements and Other Evidence under Directive 2014/104/EU: An Undue Prominence of Public Enforcement?
}

\author{
Claudia Massa
}

\begin{abstract}
Directive 2014/104/EU contains detailed provisions related to the disclosure of evidence in actions for damages before national courts that seek to strike a balance between a claimant's right to access evidence in support of its private damages claim and the protection of leniency programmes, which are some of the main tools of public antitrust enforcement. Articles 5 to 8 of the Directive create a "microsystem" of the law of the evidences, which is highly specialised and based on the central role of the judge and on the principle that private enforcement must not compromise public enforcement.
\end{abstract}

The Directive tackles the information asymmetry that characterises competition law litigation by acknowledging the right for a claimant "to obtain the disclosure of evidence relevant to their claim, without it being necessary for them to specify individual items of evidence". However, the obtainment of the disclosure of evidence is circumscribed by a number of conditions and exceptions.

The Directive creates three lists of documents that are characterised by a different level of protection: the black list, the grey list and the white list.

After giving an overview of all these provisions, the article will focus on the disclosure of leniency statements and settlement submissions, by analysing the case law of the ECJ before and after the entry into force of the Directive. It will be found out that while the Court has always been cautious, by affirming that it is necessary to weigh up, on a case-by-case basis, the respective interests in favour of disclosure of such documents and those in favour of their protection, the European Legislator preferred to unconditionally protect the efficiency of leniency and settlement programmes to the detriment of parties that suffered a harm, which have to find any possible way to support their

\footnotetext{
* Claudia Massa, LLM in European Law at Panthéon Assas University (Paris II), currently PhD Candidate in Economic Law at University of Naples Federico II - Department of Law, 80129, Naples, Italy, claudia.massa@unina.it.
} 
damage claim in a context in which the information asymmetry and the difficulty of the factual and economic analysis are evident.

It seems that, with Article 6(6), the European Legislator did not succeed in its goal of making it easier for victims of antitrust violations to claim compensation from the offender, which is the general aim of the Directive. In fact, not having the possibility to have access to leniency statements or settlement submissions in stand-alone actions, it is highly difficult to prove that they suffered harm. Therefore, victims can only wait until the competition authority adopts a final infringement decision in order to start a probably successful follow-on action.

Overall, all provisions on disclosure of documents contained in the Directive contribute to make a big step forward in the private enforcement sector, except for the provisions of Article 6(6), which could have probably been less rigid. In fact, while the rule on the right to obtain the disclosure of evidence, together with the provisions on disclosure of documents contained in the grey list and in the white list, strike a fair balance between public and private enforcement and facilitate victims of antitrust violations in bringing actions for damages, the same thing cannot be affirmed for provisions on disclosure of documents contained in the black list.

KEYWORDS: private enforcement, damages actions, disclosure of evidence, leniency statements, case law.

\section{Introduction}

On 26 November 2014, the European Parliament and the Council adopted Directive 2014/104/EU on certain rules governing actions for damages under national law for infringements of the competition law provisions of the Member States and of the European Union (the so-called "Damages Directive"). ${ }^{1}$ Member States had to implement the Damages Directive in their legal systems by 27 December $2016 .^{2}$

\footnotetext{
${ }^{1}$ Directive 2014/104/EU of the European Parliament and the Council of 26 November 2014 on certain rules governing actions for damages under national law for infringements of the competition law provisions of the Member States and of the European Union, OJ L 349, 5.12.2014, 1-19.

${ }^{2}$ However, so far, only twenty Member States have communicated to the Commission the measures through which they have fully transposed it (last updated on 14 June 2017, available at http:// ec.europa.eu/competition/antitrust/actionsdamages/directive_en.html). Moreover, the Directive has to be transposed also in the EEA EFTA States (Iceland, Liechtenstein and Norway) since it is EEA-relevant. In order to do so, it needs to be implemented into the EEA Agreement (the Agreement on the European Economic Area, which entered into force on 1 January 1994) before the EEA EFTA States can adopt the relevant national measures. In fact, according to Article 102(1)
} 
This Directive tends to harmonise the rules governing actions for damages for infringements of $\mathrm{EU}$ or national competition law, in order to facilitate victims of antitrust violations to claim compensation from the offender. ${ }^{3}$ In particular, it pursues the objective of improving the enforcement of competition law both at a public and at a private level.

For this reason, it contains, among the others, detailed provisions related to the disclosure of evidence in actions for damages before national courts that seek to strike a balance between a claimant's right to access evidence in support of its private damages claim and the protection of leniency programmes, which are some of the main tools of public antitrust enforcement. Articles 5 to 8 of the Directive create a "microsystem" of the law of the evidences, which is highly specialised and which is based on the central role of the judge (Recital No. 24 et seq.) and on the principle that private enforcement must not compromise public enforcement (Recital No. 21). ${ }^{4}$

This contribution seeks to analyse the Directive's provisions on the disclosure of evidence, and then it focuses on the disclosure of leniency statements and settlement submissions, with particular regard to the rulings of the European Court of Justice delivered before and after the entry into force of the Directive.

\section{The Damages Directive's provisions on the disclosure of evidence}

\subsection{The right to obtain the disclosure}

Actions for damages for infringements of Union or national competition law typically require a complex factual and economic analysis. The evidence necessary to prove a claim for damages is often held exclusively by the opposing party or by third parties, and is not sufficiently known by, or

EEA, whenever an EEA-relevant EU legal act is amended, or a new act adopted, a corresponding amendment should be made to the relevant Annex to the EEA Agreement.

${ }^{3}$ The ECJ recognised for the first time the individual's right to seek compensation for the harm caused to them by an infringement of Articles 101 and 102 TFEU in the judgment of 20 September 2001, Courage Ltd v. Bernard Crehan and Bernard Crehan v. Courage Ltd and Others, Case C-453/99, EU:C:2001:465.

${ }^{4}$ Cf. Gabriella Muscolo, "L'accesso alla prova e lo standard probatorio", http://www.agcm.it/component/joomdoc/eventi/convegni/Muscolo_-_Laccesso_alla_prova_e_lo_standard_probatorio. pdf/download.html. 
accessible to, the claimant. ${ }^{5}$ For these reasons, the number of actions for antitrust damages is still rather low. ${ }^{6}$

The Damages Directive tackles the information asymmetry that characterises competition law litigation by acknowledging the right for a claimant "to obtain the disclosure of evidence relevant to their claim, without it being necessary for them to specify individual items of evidence" (Recital No. 15). In fact, since the evidence is an important element for bringing actions for damages for infringement of competition law, strict legal requirements for claimants to assert in detail all the facts of their case at the beginning of an action and to proffer precisely specified items of supporting evidence should be avoided because they can unduly impede the effective exercise of the right to compensation guaranteed by the TFEU.

However, the obtainment of the disclosure of evidence is circumscribed by a number of conditions and exceptions.

First of all, the claimant must present a reasoned justification containing reasonably available facts and evidence sufficient to support the plausibility of its claim for damages (Article 5(1)). Thus, disclosure can only be ordered if the claimant has made a plausible assertion, on the basis of facts reasonably available to him, that he has suffered harm as a result of an infringement of competition rules by the defendant. The claimant does not have to specify individual items of evidence but he is under a duty to specify items or categories of evidence "as precisely and as narrowly as possible" (Article 5(2)). The Damages Directive provides that "fishing expeditions", i.e. non-specific or overly broad disclosure requests, should be prevented. Therefore, requests for the general disclosure of documents in a competition authority's file or of documents submitted by the defendant in the administrative procedure would not be permissible under Article 5(2) of the Damages Directive.

\footnotetext{
${ }^{5}$ On the difficulty in obtaining access to evidence, see Alessandro Bernes, "La prova del danno e del nesso di causalità nell'azione risarcitoria derivante da 'cartello' in seguito al recepimento della direttiva 2014/104/UE”, Responsabilita' Civile e Previdenza 82, no. 3 (2017): 954.

${ }^{6}$ Maarten Pieter Schinkel and Jakob Ruggeberg, "Consolidating antitrust damages in Europe: A proposal for standing in line with efficient private enforcement", World Competition: Law and Economics Review 29, 3 (2006): 395; Aldo Frignani, "L'onere della prova nelle cause risarcitorie da illecito antitrust", Diritto ed Economia dell'Assicurazione, no. 4 (2011): 1332; Gian Antonio Benacchio, "Il private enforcement del diritto europeo antitrust: Evoluzione e risultati", in Dizionario Sistematico del Diritto della Concorrenza, ed. Lorenzo F. Pace (Naples: Jovene Editore, 2013), 16; Gabriella Muscolo, "Alcune questioni in tema di accesso alla prova nel processo antitrust”, in Concorrenza ed Effettività della Tutela Giurisdizionale tra Ordinamento dell'Unione Europea e Ordinamento Italiano, ed. Giuseppe Tesauro (Naples: Editoriale Scientifica, 2013), 209.
} 
Secondly, the national court has to order the disclosure of evidence only to the extent that disclosure would be proportionate, taking into account: "a) the extent to which the claim or defence is supported by available facts and evidence justifying the request to disclose evidence; b) the scope and cost of disclosure, especially for any third parties concerned, including preventing non-specific searches for information which is unlikely to be of relevance for the parties in the procedure; and c) whether the evidence the disclosure of which is sought contains confidential information, especially concerning any third parties, and what arrangements are in place for protecting such confidential information" (Article 5(3) letters a) to c)).

Thirdly, where national courts order evidence that is included in the file of a competition authority, i.e. the Commission's or a national competition authority's administrative file, specific rules apply that seek to protect certain categories of information from disclosure.

\subsection{The protection of specific categories of evidence}

The Damages Directive provides for an increased level of protection for certain categories of documents. In particular, as far as evidence included in the file of a competition authority is concerned, in addition to the proportionality requirement set out in Article 5(3), its disclosure has to comply with Article 6(4). The latter stipulates that when assessing the proportionality of an order for disclosure of evidence that is in the file of a competition authority, the national court must consider three more factors: a) "whether the request has been formulated specifically with regard to the nature, subject matter or contents of documents submitted to a competition authority or held in the file thereof, rather than by a non-specific application concerning documents submitted to a competition authority"; b) whether the request relates to an action for damages before a national court; and c) the need to safeguard the effectiveness of the public enforcement of competition law (Article 6(4) letters a) to c)).

\subsection{The black list: absolute exemption from disclosure}

Article 6(6) of the Damages Directive establishes a "black list" of documents that benefit from an absolute exemption from disclosure: leniency statements and settlement submissions. National courts cannot order disclosure of these materials at any point in time. Leniency statements only comprise the corporate statements, which are the oral or written information provided voluntarily by, or on behalf of, an undertaking or natural 
person to the competition authority specifically for the purpose of obtaining immunity or a reduction of fines under the Commission's or a national competition authority's leniency programme. As for pre-existing information, which consists in information that exists irrespective of the proceedings of a competition authority, it is not protected by the absolute ban of disclosure (Recital No. 28). However, the exemption from disclosure is extended to literal quotations of a leniency statement or a settlement submission in other documents (Recital No. 26).

These provisions are added to three pieces of legislation having regard to the disclosure of these kinds of evidence that were in force already before the entry into force of the Damages Directive: Regulation 1049/2001, Regulation $1 / 2003^{8}$ and Regulation 773/2004. ${ }^{9}$

Historically, claimants sought access to evidence from defendants before national courts and/or from the Commission on the basis of Regulation 1049/2001. In fact, all documents of EU Institutions are open to public access under Article 15 of the Treaty on the Functioning of the European Union (TFEU) and under Regulation 1049/2001. There are, however, exceptions to this general right of public access: for instance, the Commission may refuse access to a document where disclosure would undermine the protection of commercial interests or the purpose of inspections, unless there is an overriding public interest in disclosure..$^{10}$ Even though the Transparency Regulation applies to all areas of law and all documents,

\footnotetext{
${ }^{7}$ Regulation (EC) No. 1049/2001 of the European Parliament and of the Council of 30 May 2001 regarding public access to European Parliament, Council and Commission documents, OJ L 145, 31.5.2001, 43-48.

${ }^{8}$ Council Regulation (EC) No. 1/2003 of 16 December 2002 on the implementation of the rules on competition laid down in Articles 81 and 82 of the Treaty, OJ L 001, 04.01.2003, 0001-0025.

${ }^{9}$ Commission Regulation (EC) No. 773/2004 of 7 April 2004 relating to the conduct of proceedings by the Commission pursuant to Articles 81 and 82 of the EC Treaty, OJ L 123, 27.4.2004, 18-24. On 3 August 2015, the European Commission adopted amendments to Regulation 773/2004 and four related Notices (Access to the File, Leniency, Settlements, Cooperation with National Courts), aimed at aligning them with Directive 2014/104/EU.

${ }^{10}$ See Article 15(4) TFEU as well as Article 4 of Regulation 1049/2001. Such exceptions may be grouped into mandatory exceptions and discretionary exceptions. A mandatory exception precludes access regardless of any other interest advocating disclosure such as public security or privacy and the integrity of the individual (Article 4(1) of Regulation 1049/2001). In contrast, a discretionary exception requires a balancing of the interests for and against disclosure: $\mathrm{EU}$ institutions shall refuse access to a document where disclosure would undermine the protection of commercial interests of natural or legal persons, court proceedings and legal advice, or the purpose of inspections, investigations and audits, unless in each of these cases there is an "overriding public interest in disclosure" (Article 4(2) of Regulation 1049/2001).
} 
many requests concern antitrust cases. ${ }^{11}$ In antitrust cases, the Commission generally rejects applications for access to evidence by invoking either the exception for the protection of the commercial interests of third parties or the exception for the protection of the purpose of investigations. ${ }^{12}$

Under Article 30 of Regulation 1/2003, instead, damage claimants can obtain information in final decisions concluding the enforcement proceedings, which the Commission must publish on its website. The nonconfidential version of the Commission decision does not include certain information such as business secrets, specific references to leniency submissions, and other information covered by the principle of the presumption of innocence. Thus, there are cases where damage claimants seek to obtain the confidential version of the Commission decision through other channels. ${ }^{13}$

Lastly, Regulation 773/2004 lays down restrictive rules for the use of documents in the file relating to a proceeding under Article 101 TFEU, by confining access to the file to the parties concerned and to complainants whose complaints the Commission intends to reject, subject to the protection of the business secrets and other confidential information of undertakings and internal documents of the Commission and of the national competition authorities, and provided that the documents made available are used only for the purposes of judicial or administrative proceedings for the application of Article 101 TFEU. ${ }^{14}$

\subsection{The grey list: temporary exemption from disclosure}

Article 6(5) contains the "grey list", that is a list of categories of evidence that can be disclosed only after a competition authority has closed its proceedings by adopting a decision or otherwise. ${ }^{15}$ In particular, the Directive

\footnotetext{
${ }^{11}$ Approximately 9 per cent. Report from the Commission on the application in 2010 of Regulation (EC) No. 1049/2001 regarding public access to European Parliament, Council and Commission documents, available at: http://eurlex.europa.eu/LexUriServ/LexUriServ.do?uri=COM:2011:0492 :FIN:EN:PDF.

${ }^{12}$ Gianni de Stefano, "Access of damage claimants to evidence arising out of EU cartel investigations: A fast-evolving scenario", Global Competition Litigation Review 5, no. 3 (2012), 98.

${ }^{13}$ Gianni de Stefano, "Access of damage claimants to evidence arising out of EU cartel investigations: A fast-evolving scenario", Global Competition Litigation Review 5, no. 3 (2012), 96.

${ }^{14}$ See Articles 6, 8, 15 and 16 of Regulation 773/2004.

${ }^{15}$ Interestingly, in Italy, Article 4(8) of the Legislative Decree No. 3/2017 transposing the Damages Directive into national legislation provides for a rule which was not included in the Directive: with regard to the categories of evidence contained in the grey list, it introduces the possibility for the national court to suspend the civil proceeding until the competition authority has closed its
} 
refers to: information that was prepared by a party specifically for the proceedings of a competition authority (e.g., a party's responses to data requests or replies to a Statement of Objections or Letter of Facts), information that the competition authority has drawn up and sent to the parties in the course of the proceedings (e.g., the Statement of Objections or Letter of Facts), and settlement submissions that have been withdrawn.

The main issue concerning this rule is to assess whether the temporary exemption from disclosure applies also pending an appeal, since the Directive did not focus on this particular aspect. Given that a competition authority may have to reopen an investigation after a successful appeal, it seems credible that a temporary exemption from disclosure should be considered to apply throughout the entire appeal procedures until the competition authority's decision has become final.

Once the competition authority has closed its proceedings, the disclosure of information should still be subject to the general requirement of proportionality as embodied in Articles 5(3) and 6(4) of the Directive. The proportionality test applicable in relation to evidence included in the file of a competition authority involves: the specificity of the request with regard to the nature, subject matter or contents of documents submitted to a competition authority or held in the file thereof; the destination of the evidence to an action for damages before a national court; and the need to safeguard the effectiveness of the public enforcement of competition law.

\subsection{The white list: no exemption from disclosure}

Article 6(9) provides for a general rule of disclosure of evidence included in the file of a competition authority, defining by default the so-called "white list": the evidence that does not fall in any of the categories qualifying for absolute or temporary exemption from disclosure may be the subject of an order for disclosure by national courts at any time. This category of information includes pre-existing information, even if submitted in the context of a leniency or immunity application. With regard to the disclosure of documents attached by the leniency applicant to the leniency statement,

proceedings by adopting a decision or otherwise. This rule tends to guarantee consistency between the proceeding before the competition authority and the civil proceeding for damages, taking into account the binding effect of the final decisions adopted by the competition authority. See Fabio Ferraro, "L'esibizione e l'utilizzo delle prove del fascicolo dell'Autorità garante della concorrenza", in Il Risarcimento del Danno nel Diritto della Concorrenza, ed. Pietro Manzini (Torino: Giappichelli, 2017), 57. 
the Directive lacks an ad hoc rule, hence, it seems that they should follow the general rule set out in Article 6(9). ${ }^{16}$

Obviously, even for that category of information, the general rules on proportionality of the disclosure and the specificity of the disclosure request apply.

\subsection{Use restrictions}

In order to prevent the abuse of the right to obtain the disclosure of evidence, the Damages Directive provides for some use restrictions imposed on parties that obtained evidence through access to a competition authority's file (Article 7). Thus, evidence falling within the scope of the absolute exemption from disclosure, and which is obtained solely through access to the file of a competition authority, is deemed inadmissible or otherwise protected under applicable national rules. The same rule is valid for evidence falling within the scope of the temporary exemption from disclosure but only until the competition authority has closed its proceedings. Lastly, evidence which is obtained by a natural or legal person solely through access to the file of a competition authority and which does not fall under the two above-mentioned categories, can be used in an action for damages only by that person or by a natural or legal person that succeeded to that person's rights, including a person that acquired that person's claim.

\subsection{Penalty provisions}

Finally, Article 8 provides for penalties that national courts have to impose on parties, third parties and their legal representatives in case of violation or abuse of the right to obtain the disclosure of evidence. In particular, penalties have to be imposed: in case of failure or refusal to comply with the disclosure order of any national court; in the event of destruction of relevant evidence when "a claim for damages is initiated or [...] an investigation by a competition authority is started" (Recital No. 33); in case of failure or refusal to comply with the obligations imposed by a national court order protecting confidential information; and when there is a breach of the limits on the use of evidence provided for in the Directive.

\footnotetext{
${ }^{16}$ Cristina Lo Surdo, "Programmi di leniency, accesso e divulgazione nel giudizio civile alla luce della Direttiva sul danno antitrust”, 4, http://www.osservatorioantitrust.eu/it/programmi-dileniency-accesso-e-divulgazione-nel-giudizio-civile-alla-luce-della-recente-direttiva-sul-dannoantitrust/.
} 
Even though Member States have freedom in determining what penalty to apply in relation to breaches of the disclosure requirements, the Directive prescribes that the penalties shall include the possibility "to draw adverse inferences, such as presuming an issue to be proven or dismissing claims or defences in whole or in part, and the possibility to order the payment of costs" (Article 8(2)).

\section{A focus on the disclosure of leniency statements and settlement submissions}

\subsection{The case law before the entry into force of the Damages Directive}

The rationale behind Article 6(6) - that provides for the absolute exemption from disclosure of leniency statements and settlement submissions - is obviously to safeguard the attractiveness of these two tools, avoiding that the participants to a cartel, influenced by the possibility of an action for damages, may desist from cooperating with the antitrust authority. ${ }^{17}$

Hence, the European Legislator preferred to unconditionally safeguard the effectiveness of public antitrust enforcement rather than the interest of the person who suffered a harm that may want to bring an action for damages having access to the documents related to a leniency or settlement programme.

On the contrary, this was not the case for the European Court of Justice (CJEU), which has always been careful in balancing the interests at stake.

In fact, in June 2011, in its judgment Pfleiderer, ${ }^{18}$ the Court of Justice (ECJ) ruled on a case concerning the refusal of a national competition authority to grant the access to the complete case-file, including the leniency documents. The Court held that a person who has been affected by an infringement of EU competition law and is seeking to obtain damages must not be precluded from being granted access to documents relating to a leniency procedure involving the perpetrator of that infringement. However, the courts and tribunals of the Member States, on the basis of their national law, have to determine the conditions under which such access must be permitted or refused by weighing the interests protected by EU law. ${ }^{19}$ In particular, they have to weigh, on a case-by-case basis, the respective interests in favour of disclosure of the information and in favour

\footnotetext{
${ }^{17}$ Ferraro, "Lesibizione", 55.

${ }^{18}$ Judgment of 14 June 2011, Pfleiderer AG v. Bundeskartellamt, C-360/09, EU:C:2011:389.

${ }^{19}$ Ibid., paragraph 32 .
} 
of the protection of that information provided voluntarily by the applicant for leniency. ${ }^{20}$ However, Member States must exercise that competence in accordance with the limits established by EU law: they must not render the implementation of EU law impossible or excessively difficult and must not jeopardise the effective application of antitrust rules. ${ }^{21}$

Then, in December 2011, in its judgment CDC Hydrogene Peroxide, ${ }^{22}$ the General Court (GC) concluded that the interest of an undertaking which took part in a cartel in avoiding actions for damages cannot be regarded as a commercial interest and does not constitute, in any event, an interest deserving of protection under Regulation 1049/2001, having regard to the individual's right to a compensation for damages caused by anti-competitive conducts. ${ }^{23}$ For this reason, the GC annulled the Commission's decision refusing full access to the statement of contents of a case-file, which can potentially allow the applicant to identify the documents that could be useful for the purposes of a damages action.

Moreover, in 2012, in EnBW Energie, ${ }^{24}$ the GC again annulled a Commission's decision refusing access to documents included in a casefile. In this case, the alleged victim of a cartel sought access to several documents including the leniency statement, evidence provided by the leniency applicant, internal documents and elements seized during the inspections. According to the GC, the Commission's refusal was based essentially, and without a case-by-case assessment, on a possible adverse impact on its leniency programme, preventing it from carrying out its enforcement tasks efficiently. ${ }^{25}$

The Commission appealed to the ECJ, ${ }^{26}$ which set aside the judgment of the GC and applied the general presumption that the disclosure of

\footnotetext{
${ }^{20} \mathrm{Ibid}$., paragraphs 30 and 31.

${ }^{21}$ Ibid., paragraph 24. Bruno Nascimbene, "L'interazione tra programmi di clemenza e azioni di risarcimento nel diritto antitrust comunitario: prospettive in tema di collective redress", Diritto dell'Unione Europea 4 (2012), 731.

22 Judgment of 15 December 2011, CDC Hydrogene Peroxide Cartel Damage Claims (CDC Hydrogene Peroxide) v. European Commission, T-437/08, EU:T:2011:752.

${ }^{23} \mathrm{Ibid}$., paragraph 49.

${ }^{24}$ Judgment od 22 May 2012, EnBW Energie Baden-Württemberg AG v. European Commission, T-344/08, EU:T:2012:242.

${ }^{25} \mathrm{Ibid}$., paragraph 72.

${ }^{26}$ Judgment of 27 February 2014, European Commission v. EnBW Energie Baden-Württemberg AG, C-365/12 P, EU:C:2014:112. See Yves Botteman, “Access to DG Competition's files through the Transparency Regulation: An uphill battle for cartel damage claimants", 2014, 2, http://www.steptoe.com/resources-detail-9463.html.
} 
documents included in a proceeding under Article 101 TFEU undermine the protection of commercial interests and the purpose of investigations. ${ }^{27}$ According to the ECJ, only in this way Regulation 1049/2001 would be applied in accordance with Regulations $1 / 2003$ and 773/2004, ${ }^{28}$ which "do not provide a right of access to the file for third parties other than complainants". ${ }^{29}$ The ECJ believes that the interest of bringing an action for damages is not a superior interest within the meaning of Article 4(2) of Regulation 1049/2001, ${ }^{30}$ therefore any person seeking compensation must prove "that it is necessary for that person to be granted access to documents in the Commission's file, in order to enable the latter to weigh up, on a case-by-case basis, the respective interests in favour of disclosure of such documents and in favour of the protection of those documents, taking into account all the relevant factors in the case" ${ }^{31}$ However, EnBW has failed to show in what way access to all the documents relating to the proceeding in question is necessary for that purpose on the basis that there is an overriding public interest in disclosure of the documents under Article 4(2) and (3) of Regulation 1049/2001. ${ }^{32}$ Therefore, the ECJ rejected the plea.

Actually, before the ECJ ruled in February 2014 on the appeal in the EnBW Energie case, in June 2013 it gave another judgment in line with the previous ones (Pfleiderer, CDC Hydrogene Peroxide and EnBW Energie first instance judgment). The judgment in question is Donau Chemie, ${ }^{33}$ in which the ECJ reaffirmed what was said in Pfleiderer and added that: "it is only if there is a risk that a given document may actually undermine the public interest relating to the effectiveness of the national leniency programme that non-disclosure of that document may be justified". ${ }^{34}$ In any other case, the case-by-case weighing-up is necessary because any rule that

\footnotetext{
${ }^{27}$ Judgment of 27 February 2014, European Commission v. EnBW Energie Baden-Württemberg AG, C-365/12 P, EU:C:2014:112, paragraphs 80, 81, and 93.

${ }^{28}$ Ibid., paragraphs 92, 93 and 94. In fact, Regulations Nos. 1049/2001 and 1/2003 do not contain a provision expressly giving one regulation primacy over the other, so it is necessary to ensure that each of the regulations is applied in a manner which is compatible with the other and enables them to be applied consistently (see Judgment of 27 February 2014, European Commission v. EnBW Energie Baden-Württemberg AG, C-365/12 P, EU:C:2014:112, paragraph 84).

${ }^{29} \mathrm{Ibid}$., paragraph 94.

${ }^{30} \mathrm{Ibid}$., paragraph 108.

${ }^{31} \mathrm{Ibid}$., paragraph 107.

${ }^{32} \mathrm{Ibid}$., paragraph 132.

${ }^{33}$ Judgment of 6 June 2013, Bundeswettbewerbsbehörde v. Donau Chemie AG and Others, C-536/11, EU:C:2013:366.

${ }^{34} \mathrm{Ibid}$., paragraph 48 .
} 
is rigid, either by providing for absolute refusal to grant access to the documents in question or for granting access to those documents as matter of course, is liable to undermine the effective application of Articles 101 and 102 TFEU. ${ }^{35}$

In 2014, in the Schenker judgment, ${ }^{36}$ the GC confirmed the position adopted by the ECJ in EnBW Energie. This time, the undertaking Schenker requested, principally, the disclosure of the entire case-file relating to the proceedings or, in the alternative, of the full text of the airfreight decision and, in the further alternative, of the non-confidential version of that decision. ${ }^{37}$ Again the Commission invoked Regulations 1049/2001, 1/2003 and 773/2004 to avoid the disclosure. The Court held that the disclosure of that information "could dissuade potential leniency applicants from making statements under those notices. Indeed they could find themselves in a less favourable position than that of other undertakings which participated in the cartel and which did not cooperate with the investigation or which cooperated to a lesser extent". ${ }^{38}$ Therefore, the Court applied the general presumption that the disclosure of documents gathered by the Commission undermines, in principle, both the protection of the purpose of inspections, investigations and audits of the institutions of the European Union and the protection of the commercial interests of the undertakings involved in such a procedure. ${ }^{39}$

\subsection{Comments}

Indeed, the Damages Directive, by categorically exempting leniency statements and settlement submissions from disclosure, contradicts the CJEU's rulings in Pfleiderer, ${ }^{40}$ Donau Chemie ${ }^{41}$ and EnBW Energie (first instance judgment), which required national courts to balance interests on a case-bycase basis when assessing the scope of disclosure. However, the Pfleiderer and Donau Chemie judgments based the national court's competence to conduct a balancing exercise on the "absence of EU rules governing the

\footnotetext{
${ }^{35}$ Ibid., paragraphs 31-34.

${ }^{36}$ Judgment of 7 October 2014, Schenker AG v. European Commission, T-534/11, EU:T:2014:854.

${ }^{37} \mathrm{Ibid}$., paragraph 2.

${ }^{38}$ Ibid., paragraph 56.

${ }^{39} \mathrm{Ibid}$., paragraphs 57, 85, 92-94 and 113-117.

${ }^{40}$ Judgment of 14 June 2011, Pfleiderer AG v. Bundeskartellamt, C-360/09, EU:C:2011:389, paragraph 31 .

${ }^{41}$ Judgment of 6 June 2013, Bundeswettbewerbsbehörde v. Donau Chemie AG and Others, C-536/11, EU:C:2013:366, paragraph 43.
} 
disclosure of documents for the purpose of antitrust damages actions". ${ }^{42}$ Now, thanks to the entry into force of the Damages Directive, there are EU rules governing the disclosure of documents for the purpose of antitrust damages actions that include the categorical exemption of leniency statements and settlement submissions from disclosure. For this reason, it seems that the Directive is inspired by the more recent judgments Schenker and $E n B W$ Energie (appeal judgment) that apply the general presumption that the disclosure of documents included in a proceeding under Article 101 TFEU undermines the protection of commercial interests and the purpose of investigations, thus, more in general, such a disclosure weakens public antitrust enforcement.

Anyway, the ECJ has never been as strict as the European Legislator in the Directive, because it left (both in Schenker and EnBW Energie) the possibility to any person seeking compensation to prove the necessity to be granted access to documents in the Commission's file, in order to enable the Commission to weigh up, on a case-by-case basis, the respective interests in favour of disclosure of such documents and in favour of the protection of those documents. ${ }^{43}$ On the contrary, the European Legislator goes further by exempting tout court from disclosure leniency statements and settlement submissions.

\subsection{The case law after the entry into force of the Damages Directive}

At this point, one might think that the CJEU's case law has changed after the entry into force of the Damages Directive, since it has had to deal with the new rule established in Article 6(6), which provides for an absolute exemption from disclosure of leniency statements and settlement submissions. Instead, this did not happen.

In July 2015, the GC gave a ruling on a case of disclosure of evidence included in the file of a competition authority. At issue in the Axa Versicherung judgment ${ }^{44}$ there was the request for access to the complete versions of the table of contents and a set of documents included in a Commission's case-file, based on the intention to seek compensation. The GC reaffirmed that it was open to the Commission to rely on the general

\footnotetext{
${ }^{42}$ Ibid., paragraph 25.

${ }^{43}$ See Judgment of 27 February 2014, European Commission v. EnBW Energie Baden-Württemberg $A G$, C-365/12 P, EU:C:2014:112, paragraph 107, and Judgment of 7 October 2014, Schenker AG v. European Commission, T-534/11, EU:T:2014:854, paragraph 95.

${ }^{44}$ Judgment of 7 July 2015, Axa Versicherung AG v. European Commission, T-677/13, EU:T:2015:473.
} 
presumption developed by the case law set out above in order to decide to refuse the request. ${ }^{45}$ However, the Commission needed to establish whether the general considerations were in fact applicable to the document asked to be disclosed. ${ }^{46}$ The GC also confirmed that "[a]lthough [...] [Pfleiderer and Donau Chemie] case-law concerns leniency programmes established by national competition authorities, the same reasoning may be applied, by analogy, to the leniency programme of the Commission". ${ }^{47}$ Then, the GC added that only if there was a risk that a given document may actually undermine the public interest relating to the effectiveness of the leniency programme in question that non-disclosure of that document may be justified, therefore the Commission or the national courts "must refrain from taking an inflexible and absolute stance liable to undermine either the effective application of the competition rules by the public authorities entrusted with ensuring their observance or the effective exercise of individuals' rights flowing from these rules". ${ }^{48}$ For this reason, they must weigh up, on a case-by-case basis, the different interests in favour of disclosure and in favour of the protection of the documents in question.

Finally, the GC touched the issue of the compatibility of public and private interests with the rule set out in Article 6(6) of the Directive. First of all, the GC said that the case law recognised the value of the leniency programme, "but at the same time points out that the public interest in preserving its effectiveness cannot be considered to take precedence, in a general and absolute way, over the other public and private interests at stake, which are also worthy of protection and must be reconciled with it on a case-by-case basis". ${ }^{49}$ Then, it added that Recital No. 20 and Article 6(2) of the Directive expressly state that this directive is without prejudice to the rules on public access to documents laid down in Regulation 1049/2001. ${ }^{50}$

On its first occasion of applying the rule set out in Article 6(6) of the Damages Directive, the Court preferred to bypass the problem and the only justification for such a behaviour is that the case Axa Versicherung concerned the disclosure of a table of contents with references to leniency documents and not leniency documents themselves.

\footnotetext{
${ }^{45}$ Ibid., paragraph 95.

${ }^{46}$ Ibid., paragraphs 94 and 97.

${ }^{47}$ Ibid., paragraph 118.

${ }^{48}$ Ibid., paragraphs 122 and 123.

${ }^{49}$ Ibid., paragraph 135.

${ }^{50} \mathrm{Ibid}$., paragraphs 58 and 135.
} 
So far, no other cases in which the Article 6(6) should be applied have been submitted to the court.

However, in March 2017, the ECJ gave a judgment on another important aspect of the issue at stake: the Evonik Degussa judgment on the publication of information in a Commission decision finding an infringement of Article 101 TFEU. ${ }^{51}$ In this occasion the Court held that the case law formulated on the basis of Regulation 1049/2001, under which it acknowledged that there was a general presumption capable of justifying the refusal to disclose the documents in a file relating to a proceeding under Article 101 TFEU, must not be transposed to the publication of decisions on infringements of Article 101 TFEU..$^{52}$ In fact, the publication, in the form of verbatim quotations, of information from the documents provided by an undertaking to the Commission differs from the publication of verbatim quotations from that statement itself. "Whereas the first type of publication should be authorised, subject to compliance with the protection owed, in particular, to business secrets, professional secrecy and other confidential information, the second type of publication is not permitted in any circumstances". ${ }^{53}$ Consequently, Article 6(6) of the Damages Directive is properly not mentioned at all.

Interestingly, however, Advocate General (AG) Szpunar ${ }^{54}$ makes a difference between leniency statements and factual information, thus, in his mind, "the fact that the leniency statements are afforded full protection does not mean that the same level of protection must be afforded to the factual information concerning the infringement contained in those statements when the Commission's decisions are published". ${ }^{55}$ In fact, he believes that a fundamental element of actions for damages is the public access to the information relating to the unlawful facts, "since it allows injured third parties to ascertain the course taken by the cartel and facilitates the establishment of the facts relating to the existence and the extent of liability, with respect to all the participants". ${ }^{56}$ Indeed, the delicate balance between public and private enforcement established by the Damages

\footnotetext{
${ }^{51}$ Judgment of 14 March 2017, Evonik Degussa GmbH v. European Commission, C-162/15 P, EU:C:2017:205.

${ }^{52}$ Ibid., paragraphs 77 and 79.

${ }^{53}$ Ibid., paragraphs 87 and 97.

${ }^{54}$ Opinion of AG Szpunar in Case C-162/15P, Evonik Degussa GmbH v. European Commission, EU:C:2016:587.

${ }^{55}$ Ibid., paragraph 204.

${ }^{56}$ Ibid., paragraph 204.
} 
Directive could be upset if the absolute protection afforded to leniency statements is extended to information relating to the unlawful facts contained in those statements. Therefore, AG Szpunar concludes that: "such a wide protection of the leniency documents cannot be inferred from Directive 2014/104, in the absence of any express provision to that effect". ${ }^{57}$

\section{Conclusion}

One of the reasons why the Damages Directive has been adopted is to remedy the absence of EU rules governing the disclosure of documents for the purpose of antitrust damages actions and it created a two-pillar system, based on both public and private enforcement, even though it still remains focused on the first one: the key rules are, in fact, those on the access to information held by the competition authorities and on the binding effect of their decisions for the national courts.

The most relevant issue in the field of disclosure of evidence arises from the need for an interaction between public and private enforcement, since the disclosure of evidence - especially of that contained in leniency or settlement's case-files - could jeopardise the application of competition rules by antitrust authorities.

While the rule on the right to obtain the disclosure of evidence contained in the Damages Directive, together with the provisions on disclosure of documents contained in the grey list and in the white list, strike a fair balance between public and private enforcement and facilitate victims of antitrust violations in bringing actions for damages, the same thing cannot be affirmed for provisions on disclosure of documents contained in the black list.

Indeed, the disclosure of leniency statements and settlement submissions is a very delicate matter, therefore, even before the entry into force of the Damages Directive, the CJEU dealt with this topic several times and it has always been cautious, by affirming that it is necessary to weigh up, on a case-by-case basis, the respective interests in favour of disclosure of such documents and those in favour of their protection.

Now, thanks to the entry into force of the Damages Directive, there is a legislative parameter (Article 6(6)) that the CJEU has to take into account when deciding in cases on disclosure of evidence contained in leniency or settlement case-files, therefore its jurisprudence on this topic is supposed

${ }^{57} \mathrm{Ibid}$., paragraph 205. 
to change, since a very strict rule has been introduced. The weighing up on a case-by-case basis is not permitted anymore. However, so far, the Court has not yet ruled on the matter, even though it had the opportunity to do so.

Indeed, a more balanced solution than the one adopted by the CJEU of the weighing up of the interests on a case-by-case basis is not conceivable; it seems the only method in order not to favour public enforcement over private enforcement or vice versa. Instead, the European Legislator has preferred to unconditionally protect the efficiency of leniency and settlement programmes to the detriment of parties that suffered a harm which have to find any possible way to support their damage claim, in a context in which the information asymmetry and the difficulty of the factual and economic analysis are evident.

It seems that, with this particular provision contained in Article 6(6), the European Legislator did not succeed in its goal of making it easier for victims of antitrust violations to claim compensation from the offender, which is the general aim of the Damages Directive. In fact, not having the possibility to have access to leniency statements or settlement submission in stand-alone actions, it is highly difficult to prove that they suffered harm. Therefore, victims can only wait until the competition authority adopts a final infringement decision in order to start a probably successful follow-on action. ${ }^{58}$

Overall, all provisions on disclosure of documents contained in Directive 2014/104/EU contribute to make a big step forward in the private enforcement sector, except for the provisions contained in Article 6(6), which could have probably been less rigid.

\footnotetext{
${ }^{58}$ In fact, according to Article 9(1) of the Damages Directive, the final decision adopted in accordance with Articles 101 and 102 TFEU or with national competition law by a NCA, or the final decision rendered by a court of appeal are considered irrefutable proof of the infringement in follow-on actions. Therefore, the existence of the damage will be surely recognised by the judge ruling in the action for damages, whereas the amount of the damage will be evaluated by the same judge, even though it could also be null. However, under Article 9(2) of the Directive, the binding effect is not recognised to a decision of a NCA of another Member State, different from the one where the claim for compensation has been promoted. This means that the person seeking compensation has very few possibilities, firstly because they cannot have access to leniency or settlement documents, secondly because the judge can also assess that there is no infringement and subsequently no compensation. On this point, see Claudia Massa, "The effects of decisions adopted by Competition Authorities in the framework of Directive 2014/104/EU: Criticalities and future prospects", in 60 years of EU Competition Law: Stocktaking and future prospects, ed. Roberto Mastroianni, Amedeo Arena (Naples: Editoriale Scientifica, 2017), 126-128.
} 
A possible objection to this conclusion could be that a less rigid rule for instance, the one of the weighing up on a case-by-case basis suggested by the CJEU - might discourage undertakings belonging to a cartel from cooperating with the antitrust authorities: in fact, they would be aware that, even though in principle what they confess will not be disclosed, at a later time the Court could order the disclosure of evidence included in the leniency programme, considering more appropriate to protect the victim's interests.

This is partially true. Indeed, it is true that the undertaking, participating to a leniency programme, would risk that its confessions may be disclosed (with all the subsequent consequences, such as the negative influence on the company's reputation, the potential simultaneous violation of other laws, the private antitrust lawsuits that might follow, etc.). ${ }^{59}$ but it is also true that the same undertaking, deciding to collaborate with the authority, will benefit from a whole host of advantages. In fact, according to the European leniency policy, if a company which participated in a cartel is the first one to inform the Commission of an undetected cartel by providing sufficient information to allow the Commission to launch an inspection at the premises of the companies allegedly involved in the cartel, it will obtain total immunity. On the other hand, companies which do not qualify for immunity may benefit from a reduction of fines if they provide evidence that represents significant added value to that already in the Commission's possession and have terminated their participation in the cartel. The first company to meet these conditions is granted 30 to $50 \%$ reduction, the second 20 to $30 \%$ and subsequent companies up to $20 \%{ }^{60}$

Hence, it is a risk assessment that the company will have to deal with.

It should not be forgotten that a rule like the one contained in Article 6(6) highly protects companies that breached the law and who are also

\footnotetext{
${ }^{59}$ Amedeo Arena, "Game theory as a yardstick for antitrust leniency policy: The US, EU, and Italian experiences in a comparative perspective”, Global Jurist 11, no.1 (2011), 1935-1936.

${ }^{60}$ See http://ec.europa.eu/competition/cartels/leniency/leniency.html. National systems could differ from the European one. For instance, the Italian scheme, as amended in 2013, provides that all undertakings that do not qualify for full immunity but provide the Italian Antitrust Authority with valuable evidence can be granted a fine reduction which, as a rule, should not exceed $50 \%$ of the applicable sanction. Therefore, the Italian system links the discount percentage to the value of the evidence provided and not to chronological priority. The consolidated text of the Italian resolution on non-imposition and reduction of sanctions is available at: http://www.agcm.it/ratingdi-legalita/107-concorrenza/intese-e-abusi/6571-comunicazione-sulla-non-imposizione-e-sullariduzione-delle-sanzioni-ai-sensi-dellarticolo-15-della-legge-10-ottobre-1990-n-287.html. For a comparison of leniency policy in the US, EU and Italy, see Arena, “Game theory”, 1938-1941.
} 
being offered the possibility to benefit of reduction of fines, even though all in the name of the right functioning of the market. Is it not the case to mitigate such protection, so much unbalanced towards public enforcement, and to take more into account victims of illegal behaviours? If Article 6(6) were less rigid, the Commission and the NCAs would still retain the role of effective competition law enforcers, although their work could become more difficult, as the number of applications of leniency programmes could certainly decrease.

Therefore, the real issue is the following: how much can the effectiveness of private enforcement in stand-alone actions be sacrificed in order to protect public enforcement? If we considered the possibility for victims of violations of competition law to propose only probably successful followon actions (only after the infringement decision adopted by the antitrust authority has become final) sufficient, then Article 6 (6) could be considered efficient, especially since the provision of a clear, although rigid, rule is a value in itself, as it guarantees legal certainty and predictability of the consequences of participating in a leniency programme. If, on the contrary, the legislator wants to give those victims the chance to obtain damages already in stand-alone actions, then Article 6(6) should be amended and made less rigid.

\section{Bibliography}

Arena, Amedeo. "Game theory as a yardstick for antitrust leniency policy: The US, $\mathrm{EU}$, and Italian experiences in a comparative perspective”. Global Jurist 11, no. 1 (2011): 1934-2640.

Benacchio, Gian Antonio. "Il private enforcement del diritto europeo antitrust: Evoluzione e risultati”. In Dizionario Sistematico del Diritto della Concorrenza, edited by Lorenzo F. Pace, 16-26. Naples: Jovene Editore, 2013.

Bernes, Alessandro. "La prova del danno e del nesso di causalità nell'azione risarcitoria derivante da 'cartello' in seguito al recepimento della Direttiva 2014/104/UE”. Responsabilita' Civile e Previdenza 82, no. 3 (2017): 954-985.

Botteman, Yves. Access to DG Competition's files through the transparency regulation: An uphill battle for cartel damage claimants, (2014), accessed March 26, 2018. http:// www.steptoe.com/resources-detail-9463.html.

De Stefano, Gianni. "Access of damage claimants to evidence arising out of EU cartel investigations: A fast-evolving scenario". Global Competition Litigation Review 5, no. 3 (2012): 95-110. 
Ferraro, Fabio. "L'esibizione e l'utilizzo delle prove del fascicolo dell'Autorità garante della concorrenza". In Il Risarcimento del Danno nel Diritto della Concorrenza, edited by Pietro Manzini, 44-59. Torino: Giappichelli, 2017.

Frignani, Aldo. "L’onere della prova nelle cause risarcitorie da illecito antitrust, in Diritto ed Economia dell'assicurazione". Diritto ed Economia dell'Assicurazione 4 (2011): 1332-1337.

Lo Surdo, Cristina. Programmi di leniency, accesso e divulgazione nel giudizio civile alla luce della Direttiva sul danno antitrust, accessed March 26, 2018. http://www.osservatorioantitrust.eu/it/programmi-di-leniency-accesso-e-divulgazione-nel-giudizio-civile-alla-luce-della-recente-direttiva-sul-danno-antitrust/.

Massa, Claudia. "The effects of decisions adopted by Competition Authorities in the framework of Directive 2014/104/EU: Criticalities and future prospects". In 60 Years of EU Competition Law: Stocktaking and Future Prospects, edited by Roberto Mastroianni and Amedeo Arena, 113-128. Naples: Editoriale Scientifica, 2017.

Muscolo, Gabriella. "Alcune questioni in tema di accesso alla prova nel processo antitrust". In Concorrenza ed Effettività della Tutela Giurisdizionale tra Ordinamento dell'Unione Europea e Ordinamento Italiano, edited by Tesauro Giuseppe, 209-214. Naples: Editoriale Scientifica, 2013.

Muscolo, Gabriella. "Laccesso alla prova e lo standard probatorio", accessed March 26, 2018. http://www.agcm.it/component/joomdoc/eventi/convegni/Muscolo_-_ Laccesso_alla_prova_e_lo_standard_probatorio.pdf/download.html.

Nascimbene, Bruno. "L'interazione tra programmi di clemenza e azioni di risarcimento nel diritto antitrust comunitario: Prospettive in tema di collective redress". Il Diritto dell' Unione Europea 4 (2012): 731-748.

Schinkel Maarten, Pieter and Ruggeberg Jakob. "Consolidating antitrust damages in Europe: A proposal for standing in line with efficient private enforcement”. World Competition: Law and Economics Review 29, 3 (2006): 395-420. 